\title{
Extensive maxillofacial and oral myiasis
}

\author{
Felipe P Daltoé, André Ricardo Nosé, Rodrigo C Mosca, \\ Andrea Mantesso
}

\section{CASE REPORT}

A 28-year-old homeless man was brought by a police officer to the emergency service of the Regional Sul Hospital (Sao Paulo, Brazil) for evaluation of an extensive destruction of the oral and maxillofacial tissues. The patient was a heavy smoker (three packs of cigarettes per day) and according to his medical records he had a previous diagnosis of oral squamous cell carcinoma, but decided not get it treated. Three years later, the surface of the swelling revealed an extensive necrotic ulcer extending to the mouth, lips, nose and neck with live maggots visible and moving. Around 110 larvae were surgically removed and the necrotic tissue was debrided (Figure $1 \mathrm{~A}-\mathrm{B}$ ). The patient was sent to the oncology service for a whole body evaluation, however, he passed away two weeks later due to systemic complications.

\section{DISCUSSION}

The term myiasis is applied to the injurious action that a parasites of the order Diptera causes to the living or dead tissue in which they grow in vertebrates

Felipe P Daltoé ${ }^{1}$, André Ricardo Nosé ${ }^{2}$, Rodrigo C Mosca ${ }^{3}$, Andrea Mantesso ${ }^{1}$

Affiliations: ${ }^{1}$ Department of Oral Pathology, School of Dentistry, University of São Paulo, Brazil; ${ }^{2}$ Department of Bucomaxilofacial Surgery, School of Dentistry, Paulista University, Brazil; ${ }^{3}$ Department of Biotechnology, Institute of Energetic and Nuclear Research/National Committee of Nuclear Energy, University of São Paulo, Brazil.

Corresponding Author: Dr. Andrea Mantesso; Oral Pathology Discipline - Dental School - University of São Paulo., Av. Professor LineuPrestes, 2227 - CEP: 05508900 - São Paulo/SP. Brazil; Phe: + 5511 30917902; Fax: + 5511 30917814; Email: mantesso@usp.br

Received: 10 May 2012

Accepted: 04 June 2012

Published: 01 January 2013
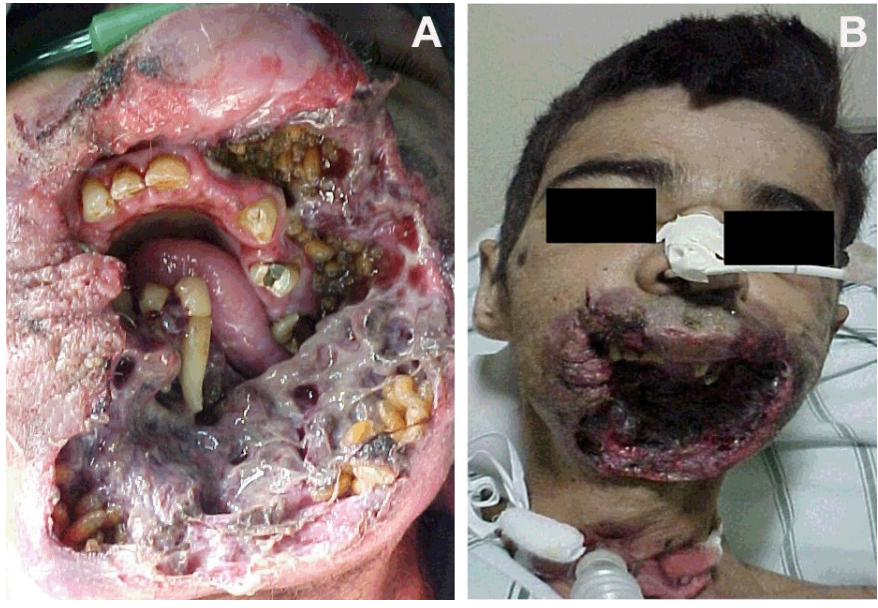

Figure 1: (A, B) Clinical picture of the patient upon arrival at the hospital. It was possible to observe an extensive necrotic ulcer extending to the mouth, lips, nose and neck with visible live maggots. Around one hundred ten larvae were surgically removed. The patient was seriously compromised and required mechanical assistance to breath.

organisms [1]. It is more common in animals and it has been rarely reported in humans [2]. Moreover, considering that myiasis develops by direct infestation of tissues by larvae (maggots) laid by flies [1], the mouth is not a common place for its development compared with dermis or other tissues.

Oral myiasis is usually associated with poor hygiene, wound healing, mouth breathing, mental impairment or senility [3]. In our case, the patient was clearly predisposed to the infestation considering the fact that he was a homeless, had unhygienic living condition, and had a previously untreated oral carcinoma.

The treatment of oral myiasis in most cases includes only surgical exploration to remove the larvae and necrotic tissue [3]. Alternatively, use of medicines such as ivermectin has also been proved efficacious, by enhancing parasitic death and their emergence to tissue surface [4]. Initial infestation can easily mimic gingival inflammations. Likewise, some cases of myiasis in association with oral tumors have also been reported [5]. 


\section{CONCLUSION}

The most effective action for prevention of human myiasis is by education and improvement of general sanitary conditions. Unfortunately, in underdeveloped or developing countries like Brazil, some people still live in poor environment associated with compromised hygiene and lack of information which can leads to human myiasis.

$* * * * * * * * *$

Daltoé FP, Nosé AR, Mosca RC, Mantesso A. Extensive maxillofacial and oral myiasis. International Journal of Case Reports and Images 2013;4(1):80-82.

$* * * * * * * * *$

doi:10.5348/ijcri-2013-01-265-CI-19

\section{Author Contributions}

Felipe P Daltoé - Substantial contributions to conception and design, Acquisition of data, Analysis and interpretation of data, Drafting the article, Revising it critically for important intellectual content, Final approval of the version to be published

André Ricardo Nosé - Substantial contributions to conception and design, Acquisition of data, Analysis and interpretation of data, Drafting the article, Revising it critically for important intellectual content, Final approval of the version to be published

Rodrigo C Mosca - Substantial contributions to conception and design, Acquisition of data, Analysis and interpretation of data, Drafting the article, Revising it critically for important intellectual content, Final approval of the version to be published

Andrea Mantesso - Substantial contributions to conception and design, Acquisition of data, Analysis and interpretation of data, Drafting the article, Revising it critically for important intellectual content, Final approval of the version to be published

\section{Guarantor}

The corresponding author is the guarantor of submission.

\section{Conflict of Interest}

Authors declare no conflict of interest.

\section{Copyright}

(C) Felipe P Daltoé et al. 2013; This article is distributed under the terms of Creative Commons Attribution 3.0 License which permits unrestricted use, distribution and reproduction in any means provided the original authors and original publisher are properly credited. (Please see www.ijcasereportsandimages.com /copyright-policy.php for more information.)

\section{REFERENCES}

1. Meinking TL, Burkhart CN, Burkhart CG. Changing paradigms in parasitic infections: common dermatological helminthic infections and cutaneous myiasis. Clin Dermatol 2003;21(5):407-16.

2. Kumar SL, Manuel S, John TV, Sivan MP. Extensive gingival myiasis - Diagnosis, treatment, and prevention. J Oral Maxillofac Pathol 2011 Sep;15(3):340-3.

3. Vale DS, Cavalieri I, Araujo MM, et al. Myiasis in palate by Cochliomyia hominivorax. J Craniofac Surg 2011 Nov;22(6):e57-9.

4. Gomez RS, Perdigão PF, Pimenta FJ, Rios Leite AC, Tanos de Lacerda JC, Custódio Neto AL. Oral Myiasis by Screwworm Cochliomy Hominivorax. Br J Oral Maxillofac Surg 2003;41(2):115-6.

5. Carvalho RW, Santos TS, Antunes AA, Laureano Filho JR, Anjos ED, Catunda RB. Oral and maxillofacial myiasis associated with epidermoid carcinoma: a case report. J Oral Sci 2008 Mar;50(1):103-5. 
Access full text article on

other devices

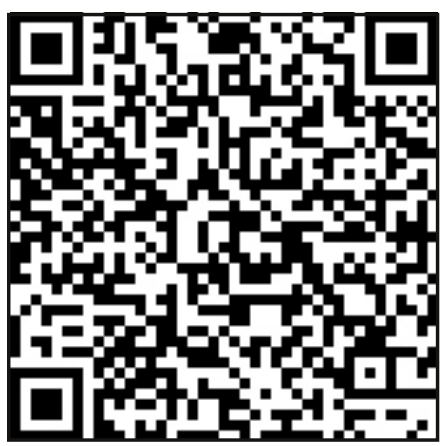

Access PDF of article on other devices

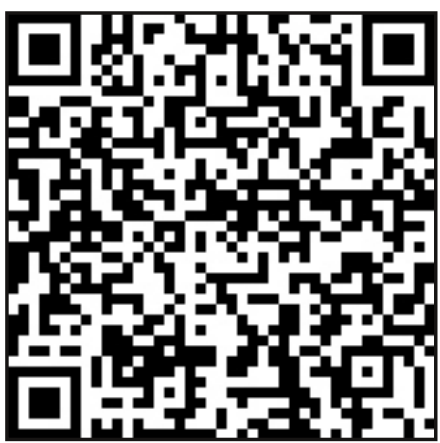

